\title{
Effect of Golden and Brown Linseed Fibre on Wheat Flour Pasting, Dough Properties and Bread Quality
}

\author{
I. ŠVEC* and M. HRUŠKovÁ \\ Department of Saccharides and Cereals, University of Chemistry and Technology Prague, \\ Technická 5, 16628 Prague, Czech Republic
}

(Received 2 March 2017; Accepted 27 June 2017; Communicated by F. Békés)

\begin{abstract}
Wheat flour was enhanced by linseed fibre, characterised by granulation 500-700 $\mu \mathrm{m}$. Using seeds from 2015 flax harvest, linseed fibre was gained from two golden and one brown linseed varieties (Amon, Raciol and Recital, respectively). Additions at levels $2.5 \%$ and $5.0 \%$ affected amylases activity and protein technological quality softly, evaluated by Falling Number and Zeleny sedimentation tests, respectively. Both brown and yellow linseed fibre significantly supported extensograph elasticity of non-fermented dough. Baking potential of composites tested evaluated as extensograph energy significantly decreased about $7-18 \%$, likely owing to dilution of dough gluten skeleton. Pasting behaviour of flour composites reflected a hydrophilic character of non-traditional material - amylograph viscosity was elevated from 590 units to ca 700 units by Amon and Recital fibre, and to ca 930 units by Raciol fibre. Pasting profiles of flour composites, recorded by using of Rapid Visco Analyser, confirmed this finding. Dough fermentation was represented by maturograph test, during which the tested samples were differentiated in part according to the dough resistance. Reflecting small modifications in dough visco-elastic properties, specific volumes of bread buns were similar trough whole sample set. A weak worsening of buns vaulting reflected a partial disruption of dough gluten skeleton. Consumer's quality of all enhanced bread variants was evaluated in category acceptable, determined as crumb penetration (values higher than $20 \mathrm{~mm}$ ).
\end{abstract}

Keywords: brown and golden linseed fibre, dough rheology, leavened bread, hierarchical cluster analysis

\section{Introduction}

Accenting healthier nutrition from consumers' side, natural sources of dietary fibre, unsaturated fatty acids and antioxidants are under concern of cereal scientists and bakery technologists. From a chemical point of view, dietary fibre is nearly always built of polysaccharides, which are basically construction elements of plant bodies or fruits. Cellulose, hemi-cellulose, arabinoxylans as well as other heteropolysaccharides, may represent a nutrition benefit for humans. Linseed fibre may contain nearly $50 \%$ of dietary fibre, due

\footnotetext{
*Corresponding author; E-mail: Ivan.Svec@vscht.cz; Phone: +420 220443 206; Fax: +420 220445130
} 
to which nutrition benefit is provable also at lower additions. Its further advantage lies in domestic production within the Europe, so it represent a relatively cheap raw-material in food production compared to, e.g. popular chia or teff seeds.

Flax (Linum usitatissimum L.) belongs to old utility plants, and its nature form was found in Asia. There are two traditional usage directions - slim stalk is a source of thread, and brown or golden seeds are raw-material for food industry. Seeds can be eaten whole, or in separated forms of linseed oil and dietary fibre. The fibre is produced as valuable by-product after oil pressing, processing linseed press cake in mill and sieving machine. Seeds cover contains 7-12\% hydrophilic heteropolysaccharides, built of neutral arabinoxylans and acid rhamnogalacturonan backbone (Kaewmanee et al. 2014). Such polymers are known as hydrocolloids, and their hydration capacity can be up to $1200 \%$ of own weight. In water at low concentrations (approx. 0.2\%, Mazza and Biliaderis 2006), they form viscous gel called mucilage (Prazdnik et al. 2016). At concentration around 1\%, flax mucilage exhibits good foam stability (Mazza and Biliaderis 2006). Ratio of the neutral sugars and proteins predetermine mucilage properties and final usage as thickener or stabiliser (Kaewmanee et al. 2014). Mucilage flow properties occur different between brown and golden flax (Troshchynska et al. 2016).

For human nutrition, linseed fibre belongs among food supplements. The New Zealand producer Walramcom (Walramcom 2017a, 2017b) presents similar chemical composition for both linseed fibre types: $45 \%$ portion of total dietary fibre $(38 \%$ insoluble and $7 \%$ soluble ones), $33 \%$ proteins and $17 \%$ fat (of which 1.7\% saturated). Recommended daily consumption of the fibre is around $13 \mathrm{~g}$. Besides good unsaturated fatty acids content, also polyphenols are represented in valuable extent (Gutiérrez et al. 2010). Diets containing flaxseed are able to correct serum lipidemia to normal values (Mervat et al. 2015).

Not linseed fibre, but wholemeal flaxseed flour is commonly used form of the alternative crop in cereal chemistry research. As mentioned supra, flaxseed flour has hydrophilic character - farinograph water absorption rose verifiably with increasing ratio of the nontraditional material in wheat flour composites (Koca and Anil 2007). Rheological properties of wheat-flaxseed flour composite dough have been stepwise worsened - dough stability and extensograph extensibility got shorter as flax flour dosage increased (Xu et al. 2014).

In comparison to control, quality parameters of wheat-flax bread with full fat or partially defatted flax flour in recipe were slightly lower, but comparable together (Mervat et al. 2015). Flaxseed hull flour had a similar impact on bread specific volume and crumb firmness (Sęczyk et al. 2017).

Aim of the study is an assessment of two additions effect of tested of golden and brown linseed fibre on rheological behaviour of wheat flour. Within laboratory baking test, also quality attributes of wheat-linseed fibre bread variants were compared. 


\section{Material and Methods}

\section{Preparation of flour composites}

Wheat flour (WF) was rendered by industrial mill Delta Prague, containing $11.2 \%$ proteins. Linseed fibre was produced at laboratory conditions, treating seeds from golden varieties Amon and Raciol and brown one Recital - all samples were prepared from flax seeds from 2015 harvest. Seeds were milled by using of mill Stephan UM/SK 5 (Stephan Machinery, Hameln, Germany), and fraction 500-700 $\mu \mathrm{m}$ was separated on vibration laboratory hand sieve machine (Stavební strojírenství n.p. Brno, Czechoslovakia). The mentioned granulation was tested in our previous study (Hrušková and Švec 2016). Wheat flour replacement ratios were analogically 2.5 or 5.0 wt. \%. Sample codes combined letters of wheat flour, addition level and the first two letters of the variety name (W2.5Am, W5.0Am, W2.5Ra, W5.0Ra, W2.5Re, and W5.0Re).

\section{Technological quality of flour composites}

By Zeleny test and Falling number, technological features of WF and flour composites were evaluated (ISO norms No. 5529 and No. 3093, respectively). Viscoelastic properties of non-fermented dough were determined with the help of extensograph Brabender (Germany), following the international norm ISO 5530-2. To determine pasting behaviour of composite flour, both amylograph Brabender according to the norm ICC 126/1 and Rapid Visco Analyser (RVA 4500, Perten Instruments, Sweden; AACC method 76-21) were employed. Rheological behaviour of leavened dough was recorded by using of maturograph Brabender, following the internal method. The rheological tests are represented by the following quality characteristics: extensograph (elasticity-to-extensibility) ratio and energy, amylograph viscosity maximum, RVA Peak Viscosity and maturograph resistance of dough. The features selection is based on experiences of our Cereal laboratory (Hrušková and Švec 2009), and aimed at depiction of linseed fibre influence on protein and polysaccharide components of wheat flour blends.

Within laboratory baking trial, all prepared wheat-flax composites were used for leavened bread manufacturing. Quality of seven bread variants was evaluated according to the internal method (Hrušková et al. 2012). Specific bread volume, bread shape and crumb penetration were determined in three replications.

\section{Statistical evaluation of linseed fibre effect}

Influence of non-traditional material type and addition level on selected dough rheological and final product features was evaluated by Tukey HSD test $(\mathrm{P}=95 \%)$ using software Statistica 7.1 (Statsoft, Tulsa, USA). Analytical tests and rheological proofs were carried out in single measurement owing to methods repeatability determined before. To find a contribution of linseed fibre type and addition level to bread quality, hierarchical cluster 
analysis was applied. For the latter method, data was standardized and resulting tree-plots of cases (samples) and variables (quality features) was built on base of the furthest clustering algorithm in Euclidean space (Hrušková et al. 2013).

\section{Results}

Flour composites - evaluation of protein quality and dough behaviour

Owing to non-gluten character of flax proteins and low enhancement level, Zeleny value of WF was lowered mildly (from $44 \mathrm{ml}$ to $37-40 \mathrm{ml}$ ). The higher addition, the lower protein technological quality is obvious for all three linseed fibre types (Fig. 1). Summarised, linseed variety did not present significant factor in results of this operational proof.

Dough machinability was changed verifiably, as indicated elasticity-to-extensibility ratio after $60 \mathrm{~min}$ of dough resting - value 1.94 of control was elevated to 2.31, 3.17 and 2.74 for dough composites W5.0Am, W5.0Ra and W5.0Re, respectively. By Tukey's test, mentioned differences were marked as significant (data not shown). Reversely, the extensograph energy decreased softly, from $128.8 \mathrm{~cm}^{2}$ to $117.5,119.6$ and $105.6 \mathrm{~cm}^{2}$ (Fig. 1) for composites in the same order as supra. Addition of linseed fibre produced from brown seeds of Recital variety caused the highest difference, although the change was provable in part only.

$\square$ Zeleny test $\square$ Extensigr. energy $\backsim$ Maturogr. resistance

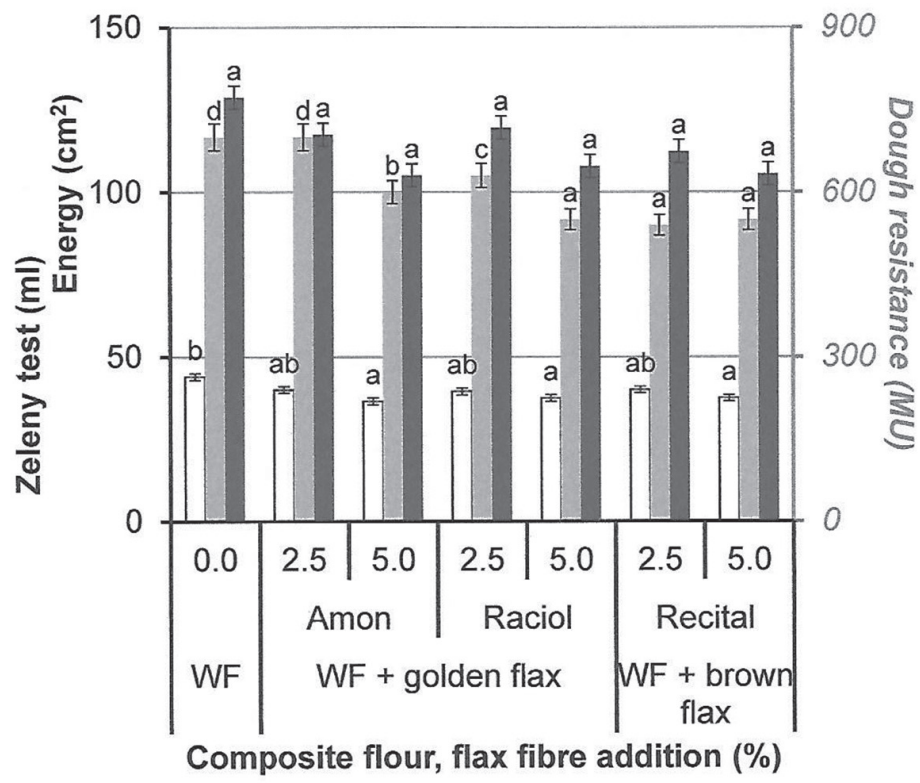

Figure 1. Effect of golden and brown linseed fibre on protein quality (Zeleny test) and dough viscoelastic properties. WF - wheat flour; a-d: columns marked with the identical letter are not statistically different $(\mathrm{p}=95 \%)$ 


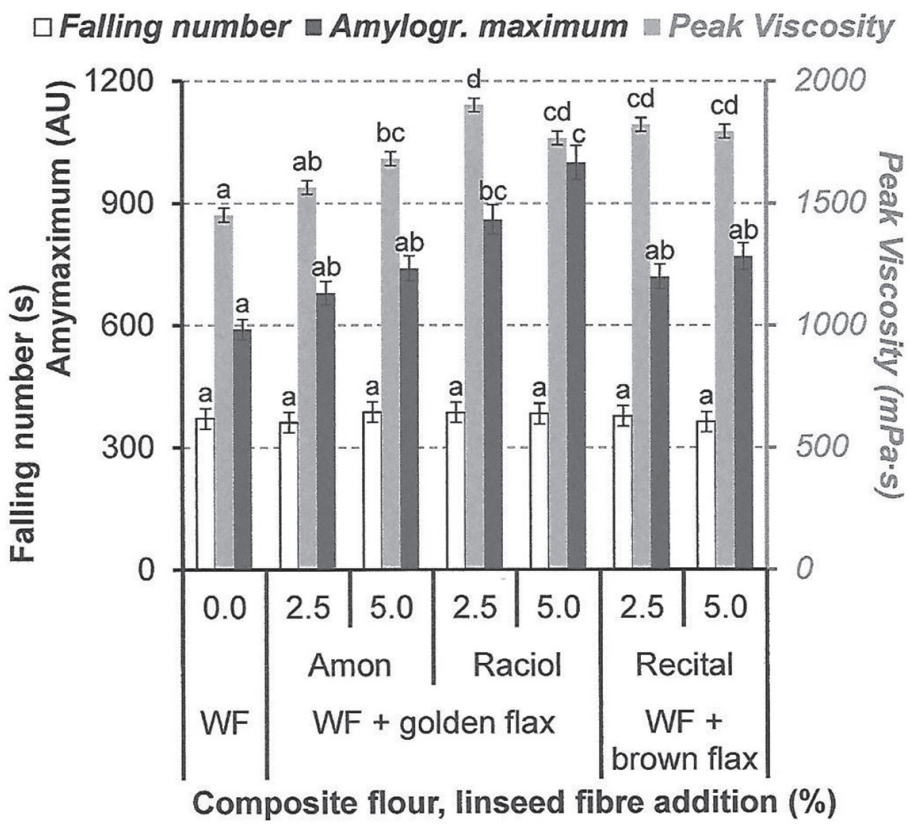

Figure 2. Effect of golden and brown linseed fibre on amylases activity (estimation by falling number) and pasting properties. WF - wheat flour; a-d: columns marked with the identical letter are not statistically different $(\mathrm{p}=95 \%)$

During maturograph test, three types of linseed fibre affected leavened dough resistance in a different way. Linseed fibre from golden Amon variety had weaker negative effect than ones from golden Raciol or brown Recital seeds did. In average, a stepwise decrease was calculated between $6 \%$ and $9 \%$ (from 700 maturograph units to 650,590 and $545 \mathrm{MU}$, respectively). For flour composites W2.5Re and W5.0Re, addition level did not represent a significant factor (540 and 550 maturograph units, respectively; Fig. 1). Considering Tukey's test results, 4 groups from 7 in total means samples differentiating from $57 \%$.

\section{Viscous and viscoelastic behaviour of flour composites}

As is known, the falling number proof represents a quick operation estimation of amylases activity and rate of damaged starch. Polysaccharides pasting is compressed into a minute, due to which determined values $362-387 \mathrm{~s}$ were found to be statistically similar within the tested flour composites set (Fig. 2). In this regard, amylograph or RVA tests are designed to describe pasting behaviour in detail; measurements are able to differentiate tested blends composition in principal points of pasting. Both for amylograph maximum and for RVA Peak Viscosity feature especially, addition level effect interacted with lin- 
seed variety factor - the highest values were determined for flour composites containing golden linseed fibre from Raciol variety (Fig. 2).

\section{Evaluation of wheat and wheat composite bread quality}

As dough machinability was varied softly by linseed fibre additions, also specific volumes of composite bread were determined in close range (331-354 ml/100 g vs. 352 $\mathrm{ml} / 100 \mathrm{~g}$ for control, Fig. 3). An extraordinary buns size from flour composite W2.5Ra $(397 \mathrm{ml} / 100 \mathrm{~g})$ could be partly connected to hand moulding of dough pieces. Bread shape was obviously more dependent on flour blend composition, indicating a medium strong role of addition level of linseed fibre. In both bread quality traits, the variants W2.5Re and W5.0Re were balanced together.

Consumer's quality of all wheat-linseed bread modification was acceptable, extrapolating this conclusion from satisfying values of crumb penetration (i.e. low texture firmness) close to or over $20 \mathrm{~mm}$ (Fig. 3).

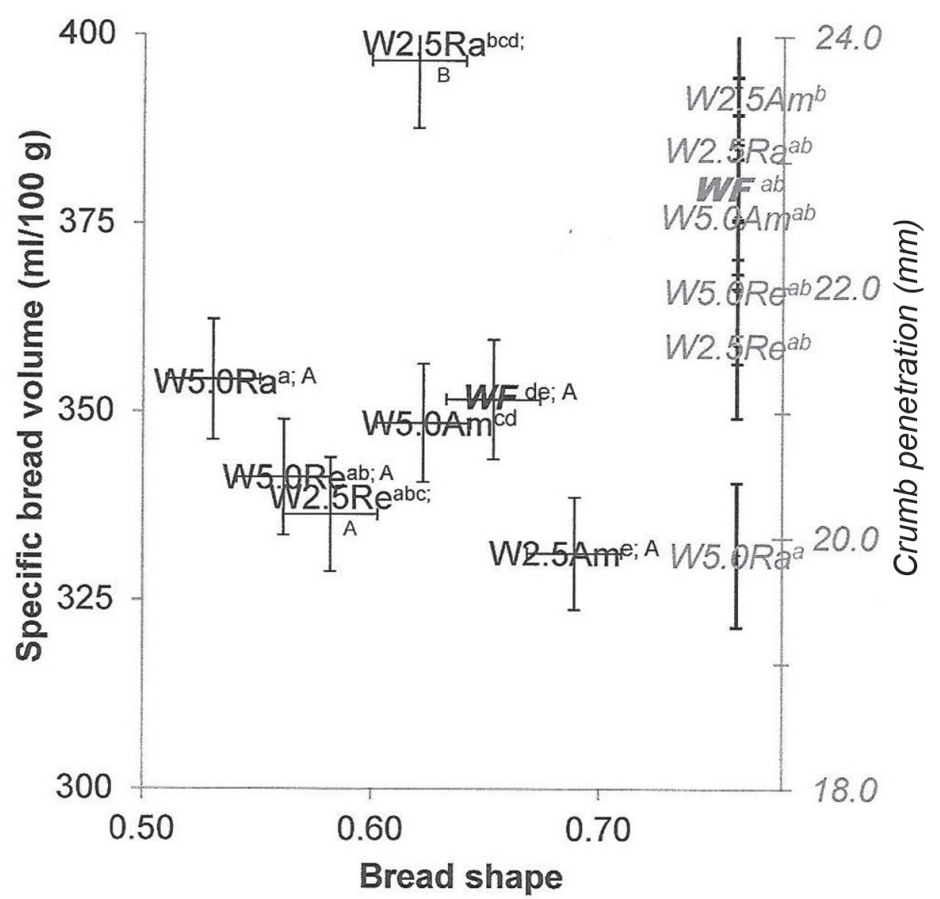

Figure 3. Effect of golden and brown linseed fibre on baking trial results. WF - wheat flour, linseed varieties: Am, Ra - Amon, Raciol (both golden one), Re - Recital (brown one). Example of flour composites abbreviation: W5.0Re - wheat flour composite, containing 5.0\% of brown linseed fibre from variety Recital. a-e, A-B: average values of bread samples shape and specific volume, marked with the identical letter, are not statistically different $(\mathrm{p}=95 \%) ; a-b$ : average values of bread crumb penetration marked with the identical letter are not statistically different $(\mathrm{p}=95 \%)$ 


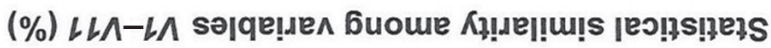

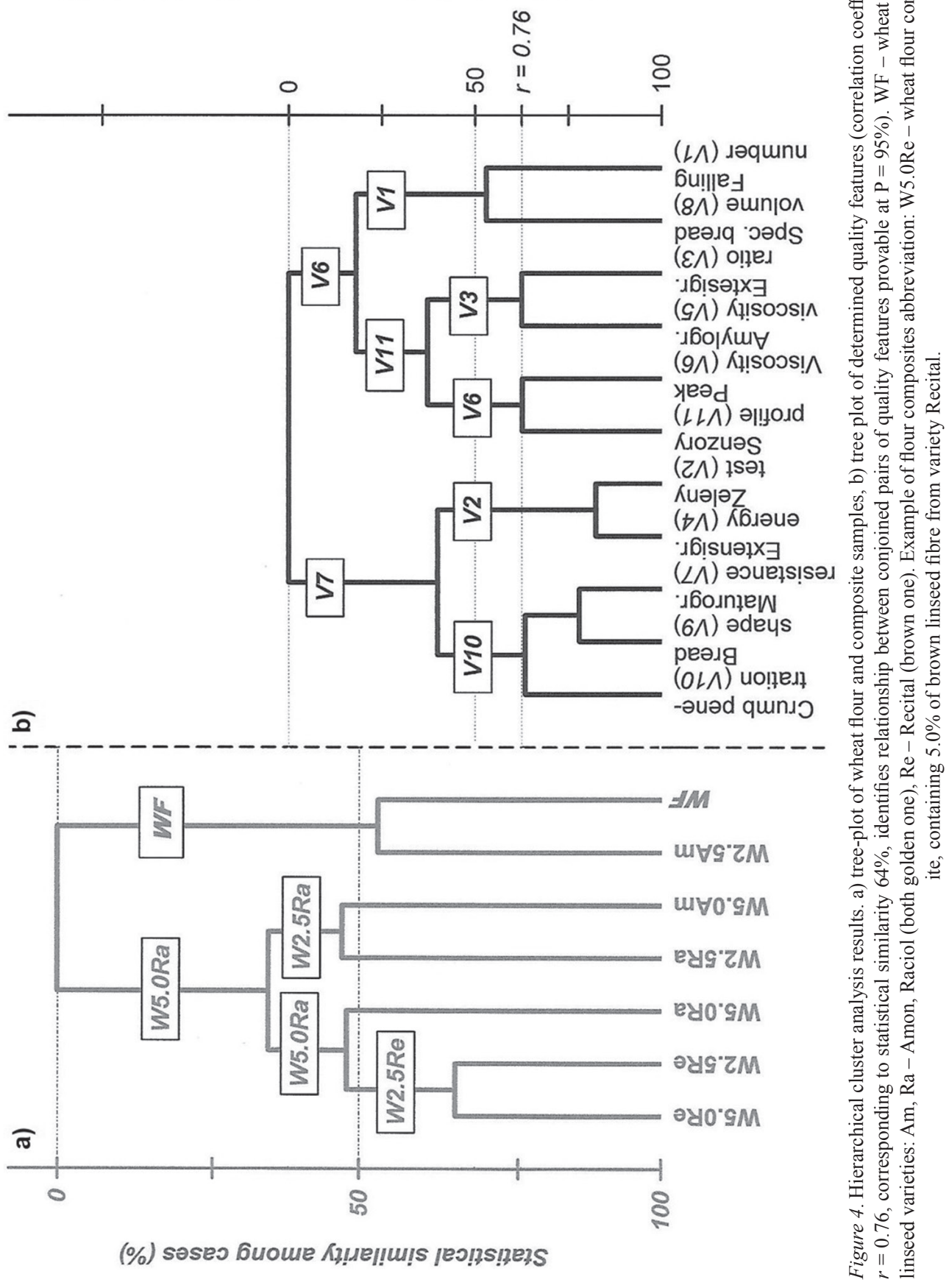

Cereal Research Communications 46, 2018 


\section{Statistical evaluation of baking potential of flour composites}

Based on complex dataset, statistical similarity among tested flour composites was not tight - it is a confirmation of partial independence of linseed fibre types and addition levels on flour, dough and bread technological quality. Constructed tree-plot of tested samples (cases) revealed out dominant effect of brown linseed fibre (variety Recital) only (Fig. 4a). The pairs WF-W2.5Am and W5.0Am-W2.5Ra (primary clusters) verifying the thesis about crossing of the observed factors.

Reciprocal relationships among observed flour composites, composite dough and bread features could be judged on base of their clustering. Statistical similarity $64 \%$ represents pair correlation verifiable on $\mathrm{p}=95 \%$ at least $\left(r_{0.05}=0.76\right)$. In Fig. $4 \mathrm{~b}$, technological characteristics of flour and dough are split into two subgroups, members of which are inclined to different bread quality parameters. Within the wheat-linseed fibre composites set, bread shape and crumb penetration are directly dependent on protein quality (Zeleny test, extensograph energy, maturograph resistance). Reversely, specific bread volume and bread sensory profile could be predicted according to the parameters of flour composites pasting.

Within both tree-plots, location of tested samples and order of recorded technological features demonstrate some tendency. From left to right, linseed fibre effect on protein quality and dough properties decreases, and reversely for pasting and bread volume. Summarised, fibre from the Recital variety influenced mainly protein part of wheat-linseed fibre composites. Besides that, fibre produced from seeds of Amon variety tends towards to impact properties of polysaccharide constituents.

\section{Discussion}

\section{Viscous and viscoelastic behaviour of flour composites}

Rheological properties of wheat composites are dependent of the linseed form tested. Linseed fibre with the same granulation but produced in New Zealand also significantly increased the viscosity during RVA test (Hrušková and Švec 2016). Reversal effect of ground flaxseed flour (GRF) mentioned Rajiv et al. (2012) and Inglett et al. (2013a). In the former case, $5 \%$ GRF softly decreased amylograph maximum, significant difference caused $15 \%$ addition. In barley-GRF mixtures, the higher portion of flaxseed flour, the lower viscosity was measured during RVA test (Inglett et al. 2013a). Comparably to flax, also chia seeds are able to form mucilage. In mixtures with barley flour, relatively flat RVA profiles (i.e. without noticeable viscosity peak) were determined similarly to flaxbarley flour blends (Inglett et al. 2013b).

Flaxseed flour had a similar influence on wheat composite dough as linseed fibre - its $5 \%$ dosage insignificantly lowered the extensograph energy (111.0 vs. $107.0 \mathrm{~cm}^{2}$, respectively; Koca and Anil, 2007). A clear drop in such bi-composite dough quality meant 20\% dosage of the non-traditional material (energy $85.0 \mathrm{~cm}^{2}$ ). 


\section{Evaluation of wheat and wheat composite bread quality}

Golden and brown linseed fibre from New Zealand caused undoubtedly worsening of bread quality, drop of specific volume came to 33\% (Hrušková and Švec 2016). Bread shape as well as crumb penetration became worse with added linseed fibre, too (e.g. range 5.8-10.4 vs. $14.3 \mathrm{~mm}$ for the latter feature). Conforti and Davis (2006) observed similar trend for flaxseed meal replacing $15 \%$ wheat flour - bread volume fell about $8 \%$ and crumb firmness rose about $40 \%$. Up to $3 \%$ in leavened bread recipe, flaxseed hulls had no verifiable negative effect on bread volume; $5 \%$ of that flax product lowered bread volume about approx. 8\% and increased crumb firmness about approx. 22\% (Sęczyk et al. 2017).

Linseed fibre as a processed by-product after oil extraction from seeds may contain nearly $50 \%$ of dietary fibre. Its bakery potential was verified in the form of leavened composite wheat-linseed fibre dough. Composite dough variants demonstrated higher water absorption, valuable feature for technological usage. In operational phase of dough proofing, such modified dough perhaps requests a shorter leavening stage to maintain optimal bread volume and texture. Between golden and brown fibre counterparts, only small differences were evaluated. From a consumer's point of view, somewhat higher attractiveness could be considered for products containing brown variant.

\section{Acknowledgements}

This work was supported by grant NAZV OI 151 027. Authors gratefully thank to Ing. Jan Kyselka, Ph.D., Department of Dairy, Fat and Cosmetics of the UCT Prague, for preparation of all linseed fibre samples.

\section{References}

Conforti, F.D., Davis, S.F. 2006. The effect of soya flour and flaxseed as a partial replacement for bread flour in yeast bread. Internat. J. Food Sci. Technol. 41 (Suppl. 2):95-101.

Gutiérrez, C., Rubilar, M., Jara, C., Verdugo M., Sineiro, J., Shene, C. 2010. Flaxseed and flaxseed cake as a source of compounds for food industry. J. Soil Sci. Plant Nutri. 10:454-463.

Hrušková, M., Švec, I. 2009. Vztahy jakostních znaků potravinářské pšenice, pšeničné mouky, těsta a pečiva. [Relationships among quality characteristics of food wheat, wheat flour, dough and bread.] Mlynářská ročenka 2009:152-182. [in Czech].

Hrušková, M., Švec, I., Jurinová, I. 2012. Changes in baking quality of composite wheat/hemp flour detected by means of mixolab. Cereal Res. Commun. 41:150-159.

Hrušková, M., Švec, I., Jurinová, I. (2013): Chemometrics of wheat composites with hemp, teff, and chia flour: comparison of rheological features. Internat. J. Food Sci. vol. 2013, Article ID 968020, 6 pages. http:// dx.doi.org/10.1155/2013/968020.

Hrušková, M., Švec, I. 2016. Flax - evaluation of composite flour and using in cereal products. Potravinárstvo 10:287-294.

Inglett, G.E., Chen, D., Lee, S. 2013a. Rheological properties of barley and flaxseed composites. Food Nutri. Sci. 4:41-48.

Inglett, G.E., Chen, D., Xu, J., Lee, S. 2013b. Pasting and rheological properties of chia composites containing barley flour. Internat. J. Food Sci. Technol. 48:2564-2570.

Kaewmanee, T., Bagnasco, L., Benjakul, S., Lanteri, S., Morelli, C.F., Speranza, G., Cosulich, M.E. 2014. Characterisation of mucilages extracted from seven Italian cultivars of flax. Food Chem. 148:60-69. 
Koca, A.F., Anil, M. 2007. Effect of flaxseed and wheat flour blends on dough rheology and bread quality. J. Sci. Food Agri. 87:1172-1175.

Mazza, G., Biliaderis, C.G. 2006. Functional properties of flax seed mucilage. J. Food Sci. 54:1302-1305.

Mervat, E.-D., Mahmoud, K.F., Bareh , G.F., Albadawy, W. 2015. Effect of fortification by full fat and defatted flaxseed flour sensory properties of wheat bread and lipid profile laste. Int. J. Curr. Microbiol. App. Sci. 4: 581-598.

Prazdnik, W., Loeppert, R., Vierstein, H., Mueller, M. 2016. Characterization of heteropolysaccharies from seed mucilage of chia (Salvia hispanica L.), basil (Ocimum basilicum L.), and flax (Linum usitatissimum L.) and their healthy functionality. In Řápková, R., Čopíková, J., Šárka, E. (eds), Proceedings of the $12^{\text {th }}$ International Conference on Polysaccharides - Glycoscience. Prague, Czech Republic. pp. 9-11.

Rajiv, J., Indrani, D., Prabhasankar, P., Rao, G.V. 2012. Rheology, fatty acid profile and storage characteristics of cookies as influenced by flax seed (Linum usitatissimum). J. Food Sci. Technol. 49:587-593.

Sęczyk, L., Swieca, M., Dziki, D., Anders, A., Gawlik-Dziki, U. 2017. Antioxidant, nutritional and functional characteristics of wheat bread enriched with ground flaxseed hulls. Food Chem. 214:32-38.

Troshchynska, Y., Synytsya, A., Kyselka, J., Štětina, J. 2016. Flaxseed meal mucilage polysaccharides: chemical characterization. In: Ǩápková, R., Čopíková, J., Š́árka, E. (eds), Proceedings of the $12^{\text {th }}$ International Conference on Polysaccharides - Glycoscience. Prague, Czech Republic. pp. 273-277.

Walramcom. 2017a. Golden flaxseed fibre composition. http://www.zdravetuky.cz/media/cms_page_media/54/ bio-lnena-vlaknina-z-zlateho-lnu.docx. accessed 20.2.2017

Walramcom. 2017b. Brown flaxseed fibre composition. http://www.zdravetuky.cz/media/cms_page_media/54/ bio-lnena-vlaknina-ze-hnedeho-lnu.docx. accessed 20.2.2017

Xu, Y., Hall III, C.A., Manthey, F.A. 2014. Effect of flaxseed flour on rheological properties of wheat flour dough and on bread characteristics. J. Food Res. 3:83-91. 